\title{
「生物物理」300 号記念特集
}

\section{座}
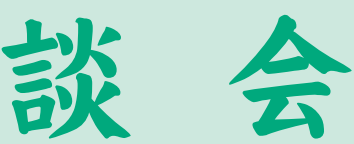

生物物理の未来

1960 年に発足した日本生物物理学会は，2010 年 12 月に創立 50 周年を迎えるにあたり，会誌「生 物物理」に特いて 50 周年記念特集「日本発の生物物理学」（50 巻 1-6 号）を企画するとともに，9月 の東北年会では記念シンポジゥムを，そして 12 月に東京の日本科学未来館にて記念式典执よび記念 講演会を開催しました。9月の年会では碩学による回顧と若手研究者によるパネルディスカッション 「生物物理の未来を語る」を行い, 12 月の 50 周年記念講演会では, 中堅研究者による「生物物理, 今 後の 50 年」と題したパネルディスカッションを行いました.

「生物物理」の 300 号では，上記のような創立 50 周年事業での取り組みと連携する立場から，「生 物物理の未来」を主題とする記念特集号として企画しました。本座談会では，パネルディスカッショ ンのメンバーを骨格として, 同世代のいわゆる「中堅の研究者」の皆さんに推まりいただきました. 50 年後につながるような将来像・未来像を展望することをめざして開始した座談会は 4 時間を超え, 熱い討議が繰り広げられました...

出 席 者
石森浩一郎
北海道大学
専門: 生物無機化学
伊藤 悦朗
徳島文理大学
専門: 神経生物学
高田 彰二
京都大学
専門: 生体分子シミュレーション
寺北 明久
大阪市立大学
専門: 光生物学

原田 慶恵

京都大学

専門：分子生理学

望月 敦史

理化学研究所

専門：数理生物学

安田 賢二

東京医科歯科大学

専門：細胞ネットワーク

若槻 壮市

高エネルギ一加速器研究機構

専門：構造生物学
司 䇥

神取 秀樹

名古屋工業大学

木寺 詔紀

横浜市立大学

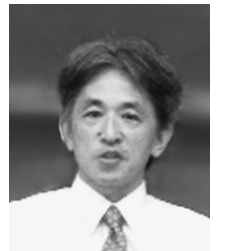

KANDORI, H

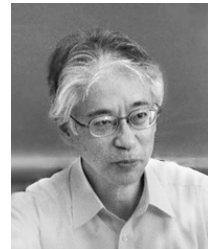

KIDERA, A 
神取 300 号記念の座談会「生物物理の未来」にご出 席いただき，ありがとらございました。私が特集号の 編集委員長を仰せつかったのも，昨年 12 月の 50 周年 記念講演会の中で「生物物理, 今後の 50 年」に関す るパネルディスカッションの司会を務めたのが縁かと 思っています。今日は皆さんの研究分野における現状 や課題をきっかけとして，50 年後につながるような 生物物理学の将来像・未来像を展望してみたいと思い ます。マクロからミクロという全体の流れで話し合っ ていきましょら。まずは「細胞ネットワーク」がご専 門の安田さんから㹉願いしす。

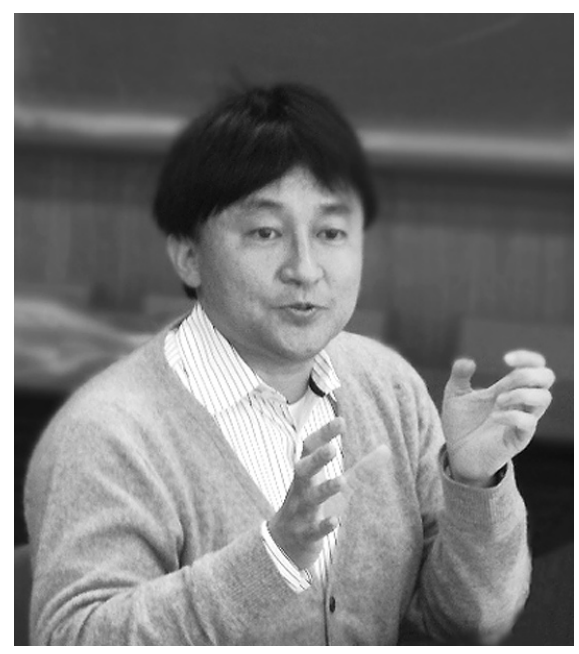

安田賢二

安田 私は生命科学を物理の一分野として考える立場 で，いちばん興味をもっているのが「集団の中の物理 現象としての生命現象」です。たとえば，通常，集団 で見られているバクテリアを1細胞だけ孤立化したと き順応力をもつのか，集団化することではじめて安定 化した行動，あるいは履歴の記憶をもつことができる のか，などのトピックに始まり，マクロファージの貪 食履歴の記憶や心筋細胞, 神経細胞のネットワークの 特性を研究してきました。物理学の一分野として生物 物理を考光るとき，生命の何を研究していくのかとい ら研究目的の軸と, ぞのようにして理解していくのか といら手法の軸，この 2 つの軸があると思いますが， 必ずとこには「物理」の言葉が入ってくると思います。 前者では，物理現象としての無生物と生物の違いの理 解，そして物理現象を生命がぞのように巧みに利用し ているかを「物理」の言葉で理解することは生物物理 の主題だと思います。トピックとしては，決定論とい ら古くて新しいモデル, 後天的な獲得情報の獲得・保 持・細胞間伝承，そして生命システムの（細胞分裂を 組み入れた）自己組織化などを物理現象としてどら説
明するのか非常に興味があります。細胞分裂といらプ ロセスは「情報の世代伝承」と「空間構造の再配置」を 進めながらより複雑な組織化を進める生命の中での固 有の（世代といら）時間軸です。つまりシステムは最初 からすべての要素が準備されているのではなく，いろ いろなものが段階的に生まれてきて破壊と創造を繰り 返して変化するのです。ここでは局所が全体を知って いるのかどらかも時間軸，空間軸をまたがった興味あ る課題です。方法論の軸についても，テクノロジ一が もつ潜在的可能性を見いだして，それを最大限利用で きる実験系を考案して実証的に利用するところにも生 物物理の「生命科学」の中での立脚点があるかと思い ます。たとえばナノテクノロジ一は，らまく使えば要 素と要素の相互作用を（同じ技術を生命の異なる階層 に用いて）時間的，空間的に厳密に操作できる可能性 を示しています。生命の世界で何が起きているか，物 質や情報の相互作用について，今までは集団平均とし て単に観察していたものが，1つ1つの要素の相互作用 という観点で実験モデルを作って検証できるのです.

木寺 生命の中で物理現象がどのように巧みに使われ ているか，物理学としてはきわめて強く一般的な原理 といらところが要求される訳ですけれぞ，たとえば生 物学といらのは常に特殊化・個別化・個別論の世界に 入っていくといら特徵がありますが，そこの切りわけ はどら拓考光でしょらか？たと光ば実際に実験をし ているシステムで細胞を使うと細胞の個性が出てきて しまいますね？そこで一般化といらのはどのように にして成立し得るのでしょらか.

安田 たとえば細胞なども, 臓器を構成している細胞 はへテロな集団です。ところがへテロでありながらあ る一定の集団サイズと空間配置になると出てくる機能 は安定します。これは生命の「集団化効果」とでもい えるでしょう。なぜ集団ではへテロさが消失するの か, あるいは要素のへテロさはどこまで許されるの か，などは生命システムの個別論とは逆の一般化への 方向をもつ課題だと思います。また手段の立場から考 えれば，最新のテクノロジーの潜在的有用性を駆使し た「構成的な方法論」によって，自然界にあるものを 分析的に見るといらスタンスだけではなくて自然界に ないものを作って見ていくことができるところが「物 理」だと思います。そういえばよく生命系の研究科に よばれて和話をすると「そこまで人工的な系を作ると 生命ではない」といわれますが，この「(既知の) 生 命ではない」といわれる研究が許されるところが「生 物物理」なのかもしれません.

若槻 高エネ研の中に 100 人くらい理論家がいますが 
生物のことに非常に興味をもってくれる人も結構い て, 物理学者として生命科学の研究に飛び込みたい, 「俺たちを誘ってくれ」というのですね，「物理は普遍 的な理論を求めるのに対して生物は各論に美学があ る, 重要性もある」と思って，理論みたいなものが生 物学で本当にできるのだろらかといら意識だと思いま す。で，今の安田さんの括話と高エネルギーの物理 学, 特に理論物理学の人たちの興味を照らし合わせる とひょっとすると，もら1つ上の枠の理論的なものを 求めているのかなといら気がします。それを生物物理 のほらがめざすのかめざさないのか, 結構大事な議論 かと思います。

木寺 今いわれたその「もら 1 つ上の枠」とは，たと えば生物とか物理とかが下にあって，もら1つ上とい らよらな?

若槻 トラディッショナルな物理の理論である必要は ないと思らのです。彼らが求めているのはあくまで統 一的に説明する，個別を包摂するような…

神取 たとえば数式みたいなものがあるといちばんい いですよね.

若槻 非常に複雑な数式でも何でいいのだと私は聞い て思っていますが，少なくとも生命現象をすべて説明 できるよらなものです。それはいわゆる物理の理論で ある必要はないといら感じがすごくします。

安田多分, その1つ前の段階, 先ほどいった集団の 物理学, 集団の生物物理学, これがまずあるべきだと 思います。

神取 安田さんの専門, 細胞ネットワークは生命科学 の将来の課題そのものであるといらららに思うのです が，たとえば実験で乗り越えなければならない課題は ぞらいらものがありますか?

安田 生物物理のいちばん重要なところとして, 決し て実験屋さんになってはいけないし，理論屋さんに なってもいけない，両方ができるような素朴な分野 (笑)，をめざさなければいけないと思います。「生物 学」にこだわらないことでシンプルな実験モデルがで きます。既存の生物学の分析的アプローチを続ける限 り, 非常に複雑で専門化していかなければいけない。 つまり生命科学の研究者が「これは生物ではない」と いわれるよらな研究プラットホームを自由に構築する ことによって，われわれはものすごくシンプルな系を 構築して「自然」に聞けばそのま答えを出してくれ る，そらいらものを作れる可能性があると思います。 つまり生物物理の強みは「生命科学じゃない」といわ れても気にする必要がない「考方方のやわらかさ」な のかもしれません。

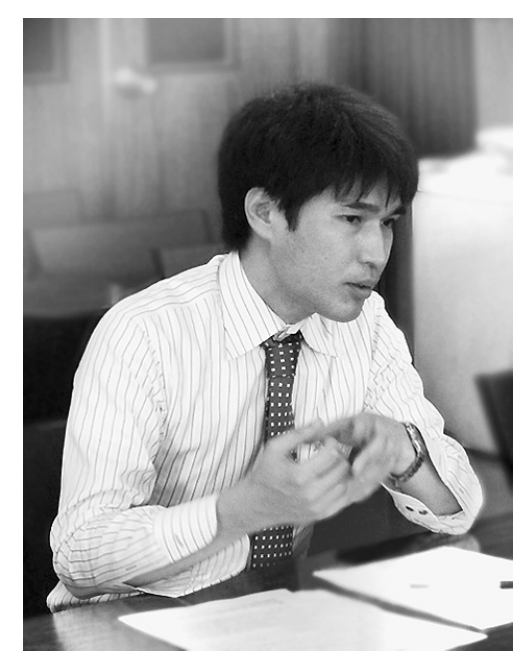

望月敦史

神取 続いて望月さん，扔願いします。

望月 私は数理生物学といら学問をやっていまして, それは生物現象に対して数理モデルや計算機を使って 研究する分野です．実はこの学問自体が生物物理学会 でインキュベートしていただいた経緯があります。こ こ 10 年の数理生物学は大きくようすを変えています. キーワードを 2 用意してきましたが，1つが生物の 階層性です。実は数理生物学は個体や集団あるいは進 化といった分野で成功してきた歴史があります，最近 の僕らの世代は，もら少しミクロな分子生物学や発生 生物学などの分野に切り込んでいくことを意識してい ます。生物学の目標の1つに階層性を打ち破り, DNAから進化まで一貫して理解したいことがあると 思いますが，そのためには何段階かの階層の壁を突破 する必要がありますね。 そこに今までと違った形で数

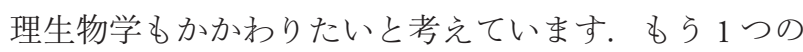
キーワードは，仮説ドリブンであるかそれともデータ ドリブンであるかといらことです。数理生物学といら のは，まず完やうと仮定やモデルを立てて，そのモ デル振る舞いを計算する，その後実験と比較して仮説 を検証するといらやり方をよくします。でも，それた けだと最近の実験の進歩を十分に取り込めません。た とえば高解像度のイメージングデータを元に数理モデ ルを作る方法や，あるいは分子種の非常に多い複雑な ネットワークのよらなデータにも切り込めるデータド リブンの要素をもった理論を作ろらとしています。つ まり数理生物学といったときにもたれる従来のイメー ジから，われわれは今大きく変わりつつあります。そ れから, 先ほどの理論物理学のよらな理論についてで すが，若梘先生がおっしゃることと同じかどらかわか りませんが, 私や皃とんどの数理生物学者は生物全体 
を説明する統一原理といらよりは，むしろ個別の文脈 で面白いと思われている現象に取り組む方針で研究を 進めています，私は生物というのは，個別の現象が面 白いと思うんです。細部を詰めていくと，非常に普遍 的な原理につながることが，いくつかの成功例でもあ ると思います。理論にもいろんな方法があるんじゃな いかなと思います。

安田 では, 数理生物学は, 生命をどう定義してるん でしょらか。

望月 答えになっているかどらかわかりませんが，わ れわれは「生命とはこのよらなものである」といった 考え方からスタートするよりは，その理論が現象の理 解に役立つかどらか，といら基準で進めるように思い ます。原理第一主義といらよりは，プラグマティズム なんだと思います。

安田 ある現象が原因であるのか，それとも結果であ るのか，一瞬を見るとその区別がつかないことがあり ます。ところが，法則を作っていくためには，原因か 結果か決めなきやいけない，そのときプラグマティズ ムでぞう選ぶんでしょう？

望月 相関する現象の，どちらが原因でどちらが結果 であるかを区別するときにこそ，プラグマティズムが 役に立つと思います。つまり，わかっている現象のら ち，Aを原因としたモデルと B の汪らを原因としたモ デル，それぞれで違いが出たとすると，どちらがより 正しいか明らかにできるというのが，わかりやすい例 だと思います。

高田階層を越えるのが生物物理の1つの目標ではな いかといわれたんですけど，私も階層性を越えて理解 したいと思っています。しかし特に理論の場合，階層 を越えるって本当に難しいと思います，具体的にいい 例は何かありますか？

望月そらですね，ちょっと待ってください。

伊藤 その間にいいですか？物理はやはり言葉が不 足していると思います。物理学自体はトップダウンで 階層を降りてくる分には対応できるわけですが，下か ら部品を積み重ねていったときには，数的爆発も起こ るし，不可能なことが多いわけです。ですから，現在 の物理は間違ってはいないですが，生物を語るにはま だまだ力不足で，だから生物物理の人たちは物理自体 を作らなければならないと思います。

神取 僕は 12 月のパネルディスカッションで望月さ んが生物学オリジナルの理論を構築したいといってい た，あれが非常に印象に残ってて，それは若㭇さんの 質問に対する答えだと思うんです。どういら風に作ら れるかはこれからの挴しみですか？
望月 近い考え方の方がたくさんいることをられしく 思っています。まず高田さんの研究って，階層を越え てるんじゃないかと思らのですけど(笑)，分子のレ ベルからファンクションを説明しよらとされてますよ ね。階層を越えることについてですが，一旦物理法則 から自由になってしまらと結構自由にできるかもしれ ません。といらのは分子生物学より上のレベルでは, 分子間の相互作用に基づいて細胞の機能や，形態形成 を理解できるようになってきています。それはモデル 的な理解だ思うんですが，分子生物学は物理学の法 則から自由になって数学や論理学を使うことによっ て，自由に階層を越えていると思うんですね。白れを 体系として定式化することが，1つ新しい理論を作る 道ではないかと思っています。だけど，古典的な物理 学と，今いった論理学をどら橋渡しするかが大事なポ イントで，高田さんが，がんばってらっしゃるのはそ こかなと。

木寺 そこがまさに高田さんの質問で，生物学が使っ ている論理学，因果関係の複雑なネットワークと，物 理的な実体をもった現象としての理解をどらつなぐか がわれわれの課題だと思うのですが，答えはあるで しょらか?

望月 難しいところを突かれたと思います。まったく その通りで，それに関しては現在具体的なアイデアは ありません、今私が申しあげられることは，大きな分 断があってその下には 1 つの理論体系がある，その上 にも新たな理論があり，これもまだまだ育てていく必 要があるといらことです。

若槻私が申しあげた，物理の人たちが生物に入って こょうとするとさの理論体系は，物理的な法則をもっ て生物学を統一理論でまとめることではないと思うん ですね。そういら意味で望月さんがいう物理の呪縛か ら外れた論理学が，望まれているアプローチだと思い ます。問題は，統一的な理解に結びつける筋道を考光 ながらやっているかどらかで違いが出てくる気がする んです。全体に結びつけることができるようになった ら，もら生物物理学じゃなくて生物なんとか学って でっかい理論にすればいいのかなって気がする。

神取 次は神経生物学を代表して, 伊藤さん报願いし ます。

伊藤 脳の高次機能を考劣ると，階層性を越えて研究 することになります。個体行動を階層を下げて調べる と, 最終的に 1 個のニューロン内の極微量の mRNA やタンパク質の量的変化まで，現時点でも容易に調べ られます。一方で, 今後 50 年後に神経生物学で何を 


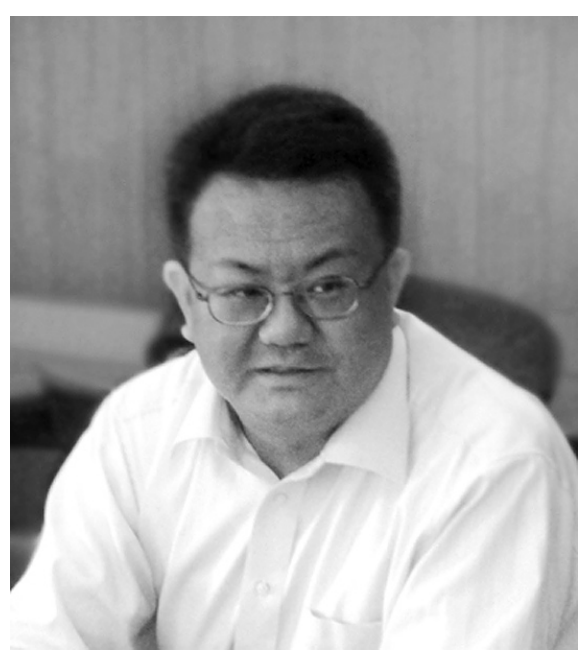

伊藤悦朗

明らかにできたらよいかというと，やはり心の問題で すね。 今は，脳の扁桃体ならびに視床下部が大事なの

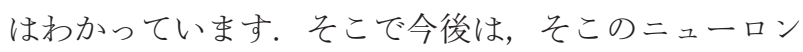
1つ1つで起こっていることを明らかにし，その情報 を元に，階層をあがり，最終的に個体が心をどのよう に発現するのかがわかるとすばらしいです。しかし， 重要なことは，部品を集めて積みあげても全体はわか らないことです。生物学では数学でいらところの組合 せ爆発のよらなことが平気で起こっていますので，新 たな物理学的解釈も必要になると思います。私はこの よらな考えですので，生物物理は生物学の1つでなけ ればならないし，物理学の1つでなければならないと 思っています。その上で，生物物理はこういらことを やってるんですよ，といら PRをし続ける努力が必要 だと思っています。

木寺 神経生物学では階層性がきわめて重要な問題で あるといわれたわけです。だけど，神経の場合，近く と巨視的に離れたところがすでに接続されている。つ まり他の分野の人たちがもっていない，階層接続のな にか特別な観点といらものがあるんじゃないですか?

伊藤 私の理解としては，他の分野と変わらないで 于.

寺北 たとえばホルモンェフェクトもそらですよね.

望月行動に対する 1 つの原理として, 適応といら言 葉があります，神経生物学を考えたときに，らまく機 能しているかどらかを適応で測るんですけれど，細胞 のレベルでも, 組織のレベルでも, 個体のレベルでも それが出てくる，だからこそ，別に細胞だけを扱って いる生物学と違わないと思います。

若槻私はむしろ今の括話は逆かなと思ったんです. 脳については, 分子レベル, 細胞レベルでいくら理解
をしても，その上の階層があたあって，そして心があ る。つまり，私の印象としては，階層が多いのかな と. しか子, 物理の人たちの階層構造と, 私たちが いってる階層構造とはまったく違らから，気をつけた 核らがいいです。

安田さきほどの適応の話ですが, 生物学者からは, 順応と適応といらのをちゃんと使いわ孙さいといわ れる，適応の場合は遺伝子まで戻っている，一方，遺 伝子ではなくて単なる履歴現象を順応であると。しか し，順応のプロセスが神経には非常に顕著に出る．神 経っていらのは細胞を見ただけでも非常にユニークだ と思う。

神取 じゃあ, 神経細胞のユニークさについて, 伊藤 さんからもらすこしご説明ください.

伊藤 ニューロンの中身を考光ている分には他の細胞 となんら変わりはないんです。人の脳の中にはたとえ ば千数百億個のニューロンがありますが，実はその ニューロン 1 個 1 個は全然違う個性をもっています. 他の例でいえば，ある特定のがんに着目しても，その がん細胞 1 個 1 個は全部個性が違っています。特段, 私としては学問分野ごとに違いがあるとは考えていな いです.

若槻 だとしたら，生物物理で心を説明できるか？

50 年かけてもいいんです.

伊藤 え光。繰り返しますが，まず 1 個 1 個の細胞で 個性を計測すること. その後，スーパーポーズして いってどらいら振る舞いをするのか，それを語る理論 を作ることです。それは，新規の原理をもち込まなく たって，カルノーサイクルを拡張した形で生物の体は 動いてるんですよ，っていらことでもよいんだと思う んです。でもそれができるのが，生物物理の人だと 思っています。

木寺 やっぱり伊藤さんがいわれたことには飛躍があ る.たくさんの個別のニューロンの計測があって，そ れをある論理で組み立てる。そこまではわかるんだけ ど，動物の振る舞いっていわれたじゃない，それを物 理学なり, 生物学として, サイエンスとしてどらやっ て記述するんですか?

伊藤 望月さんパス。（笑）

望月 先ほど順応と適応を区別しなければいけないと いらご発言がありました。私は，両者は単なる時間ス ケールの違いだと思います。環境に対する順応を，い ちばん短期的なものを順応，その次が分子の適応で， 人間の行動や，もっと非常に長期的な，すなわち 100 年以上の変化への適応が進化なんだと捉えれば同じに なると思らのです。そう考光ると，理論のレベルで神 
経細胞の適応的振る舞いを個体に解釈してもっていく ことは，難しくはないと思います。

木寺 それはいいんですが，さっき伊藤さんにした質 問の中身は，さっきの言葉でいらと心の問題といらの は，どらサイエンスで記述されるんですか？といら話 です.

望月これは本当に個人的なアイデアなんですけど も，心は過剰適応だと思います。

伊藤 いま皆さんが出してこられているいくつかの問 題を，私がごちゃごちゃに話してるのがまずいのかも しれません、つまりサイエンスとして語れるところと 語れないところを，合わせて話してしまっている。そ の点を整理した上で，木寺さんに対する答えが 50 年 後に出ればよいなあ, と思うわけですね.

神取 だけどやっぱり脳・神経の問題とか，心の問題 を明らかにするのは生物物理のような気がするよね.

伊藤はい，そら望みます。

木寺さきほどの「心は過剰適応だ」といらのは，す ごい発言でしたね.（笑）

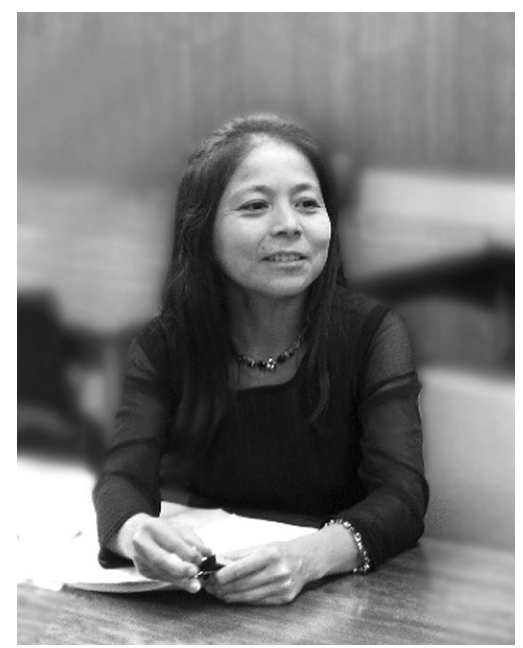

原田慶恵

神取 それでは次に分子生理学を専門とされている原 田さん，扣願いします。

原田私はもともと，タンパク質の巧みな機能につい て知りたいと思っていました。でも修士課程まではン゙ ウリムシの研究をやっていて，それが縁で大阪大学基 礎工学部生物工学科の大沢文夫先生の研究室に博士課 程から移りました。最初はゾウリムシの研究を続けて いましたが，ゾウリムシは単細胞生物ですが，1個の 細胞が非常に高度な機能をもっていて，研究するには 難しい材料でした。それで, やはりタンパク質の研究 をしょらと，柳田敏雄先生のもとで筋収縮の分子メカ ニズムの解明といらテーマで研究を始めました．筋収
縮をできるだけ簡単な形で光学顕微鏡下で再現してみ ようと，in vitro motility assay法を開発しました。その 後, やっぱり 1 個の分子の動きを見たいなと思って, ERATO の柳田プロジェクトで, 現東京大学の船津高 志さんや現東京工業大学の徳永万喜洋さんと分子 1 個 のイメージングをする実験を始めました。幸いなこと に蛍光色素 1 分子を見ることに成功し，今では 1 分子 イメージング技術を使った研究が世界中に広まってい ます。アメリカの生物物理学会に行くと，われわれが いちばんに始めたはずなのに，1 分子イメージング技 術を使った研究がぞんどん先に進んでいて，今は一矢 報いるために，新たな技術の開発をしているところで す.今後, 研究をどのように発展させていくかといら ことですが，私は，大沢文夫先生がよく扣っしゃる， 湯川秀樹先生が「生命は積み木細工ですね。量子力学 のような難しいこと，直感を越えることは何もありま せんね。脳もわかってしまいますね。」と扔っしゃっ たといら話がありますが，大沢先生と同じで，生物分 子機械は人工機械とは違う，巧みなしくみで働いてい るはずだと信じています。そしてそのしくみを明らか にすることをめざしています，巧みといっても正確に 働いているというのではなく，正確に働いているのは むしろ人工機械で，生物は間違らことを前提としてい て，多少の間違いがあっても最終的にはらまく働くし くみになっているといらところがすごいのだと思いま す。間違いを許容できるというところが生物のよいと ころだと思います。このよらなしくみを明らかにする ことが将来社会に何かしらの貢献ができるのではない かと思います。

木寺 たとえば 1 分子計測は，テクノロジードリブン の生物学の最も花形となる大成功したものですよね. 先汪どいわれていたアメリカでさらに先に進んでし まっているっていら括話かりましたけれぼ，じゃ あ, これから何をすればブレイクスルーが出てくるの か. 技術のための技術にならないといらのが非常に重 要な生物物理学としての立場だと思うんですが，何を 知りたいから何の技術を開発しなくちゃいけないの か，何か今こらいら問題に対してこらいら計測が今求 められているんだっていら，そらいらことを拈教えく ださい。

原田 ブレイクスルーは始まっています。たとえば, これまでの研究の成果で, 細胞内情報伝達の経路は解 明されたけれど，細胞の機能はまだまだわからないこ とだらけです。それを明らかにするのが生物物理学の 役目だと思うんです。だから，これからめざしている のは，細胞の中のすべての分子について，1 個 1 個の 
分子が，どのような相互作用をして全体として機能し ているのかをすべて理解しょらといらことです。もち ろんそれで本当に細胞の機能がわかるのか，確証はな いけれども，今後は細胞の中での個々の分子のふるま いを明らかにすることが重要なのではないかなと思っ ています。それを調べる方法として, 最近, 超解像顕 微鏡といら光学顕微鏡法が開発されています。これま で，光学顕微鏡の空間分解能は光の波長で規定されて いて 200 ナノメートル未満のものは理論的に見えない といわれていたのですが，巧みな方法で，今では数十 ナノメートルあるいはそれ以下の空間分解能で観察す ることができるようになってきました。

木寺 先ほど望月さんにした質問の, 論理学と実体の ある物理学をどらつなぎますか，というものの 1 つの 回答が，今の原田さんの答えにあるんだろらと思らん です．本当に細胞を見てしまって，1つの分子が 1 つ の䖢光分子の位置だといらことで，物理的な実体の中 でシステムといら論理学の記述が再構成されて理解さ れるといらことが実験的に可能になる. まさに論理学 と物理学の接続ができる可能性の1つであるといらふ らに思いました。

望月私もまったくその通りだと思います。先ほどは まだこれからだと抽しゃいましたけど，私は注意を もって原田さんたちの研究を見ていきたいと思ってい ます。

神取 日本は，もともとどこかにある技術を発展させ るのが得意だってみんないらんですけど，1 分子イ メージング技術は日本で生まれた技術です。さっきの ご発言の中で今はアメリカが結構進んでいるといわれ たのが僕はちょっと意外でしたが，それにはどらいら 背景があるのですか.

原田 やはり研究者数が多いといらことと, それから 違う分野の人と組むのがすごくうまいんです。だから われわれも他の分野の研究者ともっと積極的に話をし て，どんどん共同研究をやっていかなければいけない なと思っています。たとえば，2003年に神経化学会 と合同の年会をしたことがありますが，これからも， 違ら学会と合同年会を開催するといらような機会が あってもよいかなと思います。

神取 高田さんは生体分子シミュレーションがご専門 です.

高田 はい。私は物理化学出身ですから, 物理化学に 基ついて分子レベルの生命現象を着実に理解していき たいと思っています。最初に心をとらえたのはタンパ ク質フォールディングの問題でした。 その後は，原田

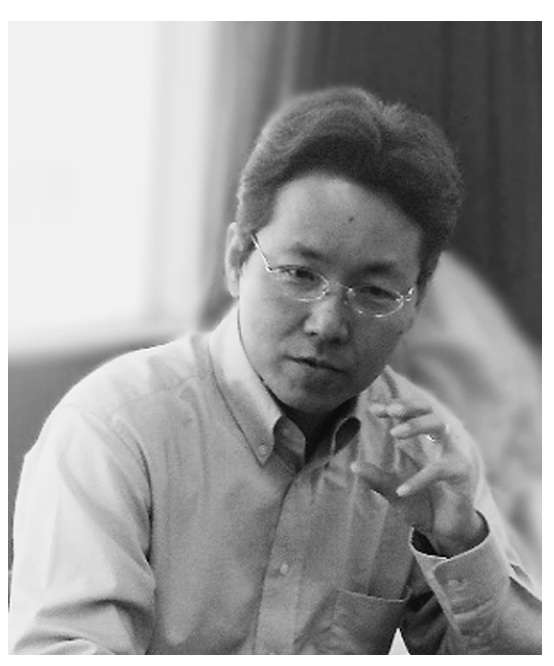

高田彰二

さんが話された分子機械, 特に分子モーターなどの研 究を行っています。分子モーターって, $0.1 \mathrm{~nm}$ スケール の化学的な素過程と $10 \mathrm{~nm}$ スケールの運動とが階層を 越えてカップルしていますよね. ミクロの化学反応が 酵素の構造変化を誘起し，それで分子がマクロに動き 始める，マクロに動き始めたタンパク質が今度はミク ロの化学反応を制御する。そのしくみを，分子シミュ レーションで理解していきたいと研究をしています.

しかし，技術的には非常に難しいのです。生体分子 シミュレーションといら分野は，この50年で著しく 拡大してはいますが，本質的な生命現象を記述するに はまだ非力です。多くの分子スケールの現象はミリ秒 以上の時間スケールで起こりますが，私たちにはマイ クロ秒しか計算できません。そこで，工夫をするしか ないわけです。私個人としては，粗視化っていら，本 質だけをとりだそうといら技術を使って階層を越えた いと考えてきました。

今後に目を向けると，2010年のScience に載った David Shaw の論文で，非常に特殊な計算機環境で，原 子レベルの 1 ミリ秒のシミュレーションを実現したっ ていらのが出ました。 これは本当にブレークスルーで す.こういうのが5〜10年で誰でもができるよらに なれば，拈そらく実験家が観察しているのと同じ現象 を，原子のレ心゙ルで観れるよらになります。もら 1 つ，私の期待は，粗視化技術で分子構造をもとにし て望月さんがいったよらな細胞レベルを説明できるよ らにすることです.さらに 50 年後には，量子力学に 基づいたシミュレーションと計算機を使ったデザイン が鍵だと思っています。

望月 分子シミュレーションといらのは, コッコッと ボトムアップ的にやる話だと思っていたんですけど 
も，高田さんのやり方は重要と思われるとこ以外を パッと切ってしまら，これはモデリングだなと思った んですね. 僕らは, 細胞レベルや発生の現象を説明する のにこの遺伝子とこの遺伝子だけが大事だっていらの で，光いやっと抜いちゃったりするんです. 高田さんの 分野では何を切り捨てるのかのコツはあるのですか?

高田 多分，一般論といらものはなくて，さっき望月 さんがいわれたように，個別論だと思うんです。個別 の問題で, 実験データを見て, 構造を見て, 最小ユ ニットは何かなどを調べて，その中の最小のことだけ を入れるしかないのです。

望月 やっぱり一般論がないってことがポイントなん ですよね，個別に，切り込む位置を決めたらそれがそ の研究者にとっての勝利の手がかり，そらいら感じな のかなと思ったんですけど.

高田まったく，その通りだと思います。

安田計算と実験のいちばんの違いって, 計算は可逆 な系で，左右同じ確率で起きると思らんです。けれ ぞ，実験系だと片方向しか絶対起きない，これが生命 の1つの神秘だと思らんです。ミクロから観ていく計 算で不可逆は説明できるんでしょらか?

高田 私は，これは単純に確率の問題だと思っていま す。自由エネルギーの高い汇らから低い注らへ流れる 確率が高い。スケールが大きくなると，落ちた自由工 ネルギーの值が大きくなり，もはや逆に行く確率はほ とんどゼロです.

木寺さっきテクノロジードリブンといら考光方が出 ましたが，その点で計算の人間って非常に lazyで，計 算機は勝手にムーアの法則で進化します。 David Shaw のAnton がそのらち使えるよらになるでしょらといら 訳です。われわれは非常に受け身だなあといら気がし ているのですけど.

高田 私個人は同感ですが，分野としてみればShaw も 生物物理の研究者です。彼はタンパク質の計算のために 専用計算機を作ったのです。実験の方がたとえば新しい 高速AFMを作るっていらのと同じです。残念ながら，日 本の, 私の近くで起こった訳じゃないといらことです.

伊藤 実験系の場合，階層は上から下だと思らんで す。たとえば光生物学はどれだけ短い時間を測れるか といらららに進んできたわけです。ところが分子シ ミュレーションは，1フェムト秒のステップを, David Shaw の論文だと，10 個集めるわけです。集めて きただけで，われわれが実際に測ってきたものと一致 するんでしょらか.

高田 たしかに，今までより長いシミュレーションを やると，最初は実験とあわない場合も多いんです。
1つ1つ原因を探って，計算を改良して越えていくわ けです。ミリ秒がどんどんシミュレーションできるよ らになれば，おそらくミリ秒で本当に起こっている現 象が観れるよらになると信じています。

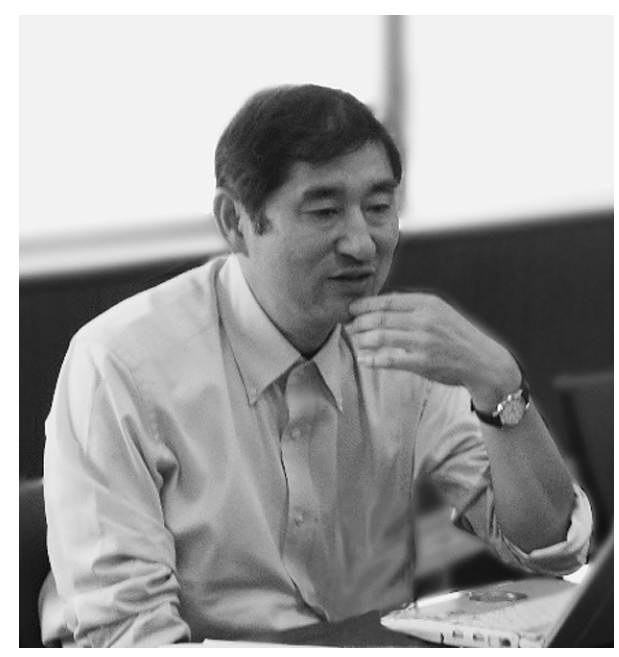

寺北明久

神取 続いて光生物学の寺北さん，和願いします。

寺北 私のバックグラウンドは生物学，専門は分子生 理学, 光生物 /視覚です。視覚にかかわるロドプシン やその仲間の光受容タンパク質の多様性に興味をもっ ています。このメンバーの中では，私がいちばん生物 物理学（会）とは距離があるか子知れません。たと光 ば，ヒトはロドプシンのなかまの遺伝子を9つもち, その半分程度はまた機能がよくわかっていません。ロ ドプシンのなかまの構造の多様性と機能の関連を明ら かにすることから，マルチな光受容タンパク質が関係 する光センシングシステムをその進化も含めて理解し たいと考えています。現在では，ロドプシンのなかま 個々の分子特性についてはある程度わかってきました が，実際それらがぞの程度異なる機能を生み出してい るのか，または協調的に機能しているのかを明らかに する段階と考光ています。機能といらのは細胞の機能 であり,さらに最終的にはどのよらな行動するのかな ぞ，個体レベルでのアウトプットです。私は，ロドプ シン分子の機能や機能発現の違いを生物物理の言葉で 説明できないか, 生物物理学的なユニークな測定方法 で機能の壁を突破できないかと思いつつ，この学会に 参加しています.

ロドプシンは，光を計測に使えるターゲットとして 研究されてきた面もありますが，そこでわかったこと を，これから生物を理解するのにどのよらに役立てる のかも今後の，たとえば 50 年先の課題だと思ってい ます。たと竞ば，多様なロドプシンのなかまを改変し 
て, GPCRのかわりに生体に置いて,さまざまな GPCR のさまざまな反応やアウトプットをすべて光で 生じさせるよらなオプトジェネティックスにより，生 命現象の複雑さを単純化して理解できるようになるの ではと期待しています。

若槻 最後のところにすごく興味があるのですが, GPCRの替わりにロドプシンのなかををエンジニアリ ングできるとしたら，いろいろな色の光に限定的に反 応し，さまざまなシグナルを出すよらなロドプシンの なかまを作る必要がありますよね。

寺北 GPCR は数千種類ありますが，細胞内に拈いて 活性化する G タンパク質の種類はたかたが数十種類 です。つまり, 細胞内のシグナル伝達システムの種類 は限定されています。ですから，特定の色に反応する ロドプシンのなかまをどのよらに用意するのかのほう が問題だと思います。吸収する波長が異なる 2 種類の ロドプシンのなかまが，1つの細胞の中に存在してい て，波長に応じて細胞内のセカンドメッセンジャ一量 を規定するといらシステムが最近発見されています. つまり, 光の強さではなく光の色により細胞の活動を 制御することが可能です.

若槻 そらだと思いますが，細胞内で起こることのシ ミュレーションと比較できるようにするには, シュミ レーションで扱ら生体分子の数に合わせて非常に多く （n色）の改変ロドプシンを用意することが必要だと 思います．50年先をいっているので，ブレイクス ルーとして本当に $\mathrm{n}$ 色に対して，それぞれの波長だけ に対応するよらなものが作れ，そしてローカリゼ一 ションもきちんと制御することができるとすごいなと 思ったのですけど、それを理論生物学の方々と，たと えばこのスイッチを入れたらこうなったよといらよら な議論できれば面白いですね.ささらに，ミリセカンド よりずっと長く，たとえば 1 年といらスケールで大き な構造のシミュレーションができると面白いですよね. 寺北 それは興味深いですね. 薬物投与だとどうして も体全体を刺激することになるのですが，光だと，光 の色を特定して特定の場所を刺激することが可能であ る点も有利だ思います。

木寺 進化についてですが，たとえば進化の何が分子 に反映されるのでしょらか？分子だけを見ていて進 化について何を語れるのでしょらか?

寺北そこがまさに，「分子からみる進化」のこれか らの問題だと思います。たとえば，情報伝達の効率が よいロドプシンのなかまと，そうでないものが使われ ている視細胞を比べると, 光に対する視細胞の応答感 度は同じくらいといら例があります。つまり，情報伝
達のカスケードのぞこかの段階で辻褄があわされるよ らな進化が起こっている訳です。分子の多様性につい ては，だんだん明らかになってきていますが，それぞ れの個々の細胞なり，個々の組織なり，個々の個体が どらいらふらにタンパク質を組み合わせて，新たな機 能的な特徵を作り出しているか, システムとしての分 子の進化・多様性の理解が大切だ思います。

木寺 分子，たとえばロドプシン，GPCRだけにとど まっていてはわからないか子しれない訳ですね。たと えば，今 1 個の分子またはその周辺のいろいろな種類 の分子を見て, そのタンパク質の進化の履歴はどの程 度わかるのでしょらか?

寺北 分子の特性が大きく変化するような変遷だけを たどると，そのタンパク質の分子進化，履歴は議論で きると思います。たとえば，ヒトが色を感じるために もつ $3 つ の$ 光受容タンパク質の進化をたどると, 分子 の履歴もわかりますし，ヒトの色覚がどのように獲得 されたか子理解できます。また，ロドプシンの吸収特 性と生活環境などもよく一致しています。ただ，タン パク質の機能を微調整的に変化させるようなアミノ酸 置換が起こっている場合，1 種類の分子を眺めても多 くの場合, 機能や分子特性の進化の履歴については明 確にはわからないと思っています。いい換えれば，シ ステムの機能やその進化を理解すれば，個々のタンパ ク質についての分子機能やその進化や多様性について 理解できると思っています。

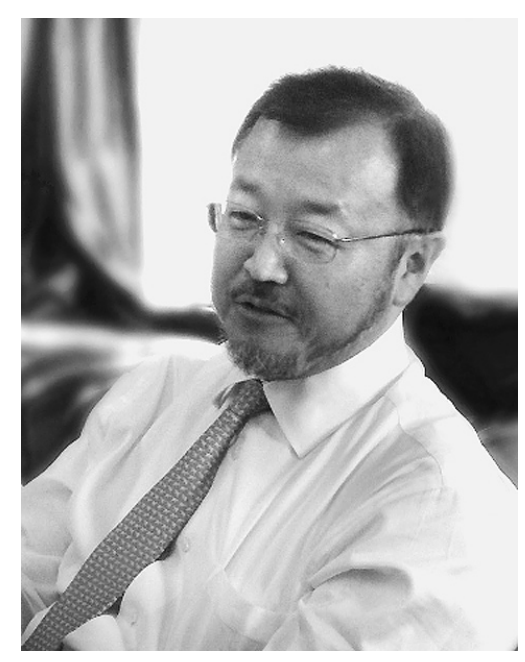

若槻壮市

神取 若梘さんには構造生物学を代表してお願いします. 若槻 若槻です. 高エネルギ一加速器研究機構という ことで，普通でいらと生物学でないところで仕事して いるよらに思われるんですけど，私の意識は生物学を やるための物理的手法, それの開発もします, といらこ 
とです。で，テクノロジードリブンといらいい方がさっ きから出てるんですけど，私は基本的な考えとしては 生物の研究をするためにテクノロジ一を作るというこ とをモットーとしています。もともとは工学部の化学 工学といらシステム工学的なところにいたのですが, 各要素のことが実はまだよくわからない状態で生態系 や生体などのシステム全体をみるといらことにフラス トレーションがありました。 したがって，生命現象に ついては要素をちゃんと見ていきたい，乙か子生体分 子それぞれを点ではなく形の動きとして見る，そのた めに必要な技術を開発し，それを使って研究するとい ら考方方をとっています。構造生物学の具体的なタ一 ゲットとしては細胞内外で生体物質がどうやって認識 されて移動するかといらことです。つまり，遺伝子に は直接書かれていない輸送や翻訳後修飾を「場の生物 学」としてとら光, 各論として個々の現象に踏み込み つつ最終的には全体像を理解したいと思っています。

この 1 年ほど構造生物学研究の将来の方向性につい て，岩田想さん，高木淳一さん，濡木理さんたちと議 論して出てきた考方方が「構造生命科学」です。それ は，構造生物学をもっと敷衍して広く生命科学にアプ ローチする，別のいい方をすると生命科学から必要と される構造生物学にするといら考方方です．X線・中 性子線結晶解析と小角散乱, NMR, 電顕, 質量分析, 計算科学などのいろいろな手法を組み合わせて相関を とり細胞分子生物学的な実験と突き合わせるといら一 連の研究の流れを作ろらといら提案です.

木寺今後の方向性の議論でミリ秒を超える時間ス ケールでもっと高次の大きな柔らかいものを対象にす るための研究手法として結晶構造解析以外にも他のい ろいろな方法をあげられた訳だと理解しますが，それ らを総合するといらことでしょらか?

若槻 構造生命科学の展開でキーになるのは, 分解能 や特性が異なる複数の構造解析手法をシームレスに 組み合わせて相関をとり多面的に原子レベルから細 胞・組織レベルまで階層構造のダイナミクスを解析す る相関構造解析法といら方向だと思います。結晶構造 解析に関しては開発されつつあるX線自由電子レー ザー（XFEL）でクォンタム・リープする可能性が高 いです。これまでは分解能に応じた放射線量の限界 (Henderson limit) が知られていますが, XFELの画期 的なことはその 3 桁 4 桁以上の量を当てても放射線損 傷が起こる前にナノ結晶から回折データがちゃんと取 れそらだといらことです。どのくらいの分解能まで出 せるかについてはまだ未知の部分はありますが.

木寺それはX線の強度が強くても照射時間を短く
することができるということですか？

若槻 数十フェムト秒といら通常の放射光パルスの千 分の一のパルス長であることがカギです。どこまで フォトン数を増やせるのか，原子分解能まで本当に正 確な構造が決められるのかが次の課題です.

石森もら1つ階層性をあげたいといら場合に構造生 物学としてどらいらことを考劣ていますか?

若槻 電子顕微鏡卜モグラフィ, 可視光イメージング とX線構造を組み合わせるといらことはもらすでに 行われています。このような複合解析をもっと多くの 手法にまで拡張して取り入れることで原子レベルから 細胞・組織レベルまでの階層構造をとらえる相関構造 解析が大事と思っています。

神取 200 号の座談会を見て今の状況と比べみると構 造生物学の進歩, 特に膜タンパクの構造解析の急激な 進展が顕著で非常に印象的です。膜たんぱく質受容体 の原子座標がわかると薬は作れますか？

若槻 たとえば，岩田想さんが最近論文発表したヒス タミン受容体については発表から 1 力月もしないらち にヨーロッパのグループとの共同研究で低分子化合物 の探索が一気に進んだそらです，GPCR 構造を解いた 当事者は皆さん創薬へつなげょらと思っています。実 際にどのくらいの時間で市場に出回るかを予測するの は難しいとは思いますが，スクリップス研究所の Ray Stevensの話では，構造なしでやっていたときに比べ て構造決定後の低分子化合物の探索プロセスは圧倒的 に成功率とスピードが上ったと聞いています。

望月 最近医学系の人たちと話したときの印象では, 僕らのやってる理論も含めて新しい生物物理的な方法 に高い関心があるようです。たと视，老化とともに 特定の分子機能レベルの分散が大きくなる，年を取る と調節が難しくなって，個体ごとにシステムごとに多 分いろいろなものの機能がばらつくんですね。病気を 理解しようとしたときにどらしてもミクロレベルの現 象，分子生物学を取り入れなくちゃいけないといら話 でした. 今こそ, 構造生物学, 生物物理から生物学, 医学の汪らにも強い橋渡しができるかもしれないと思 います。

高田 シミュレーションといら立場からですと，日本 の生体分子のシミュレーションの多くの研究者にとつ て創薬のテーマはアカデミックな興味がもたれず，真 面目に創薬のためにシミュレーションに取り組む人が 少なかったと思います。先ほどのAntonの計算機だと 多くのドラッグ分子に対して全然予備知識なしでも数 十マイクロ秒の計算をすることでかなりの確率でよい 結果に到達できるようなので，やはりこらいら分野に 
関して今からでも準備をしていく必要があるのだと思 います。

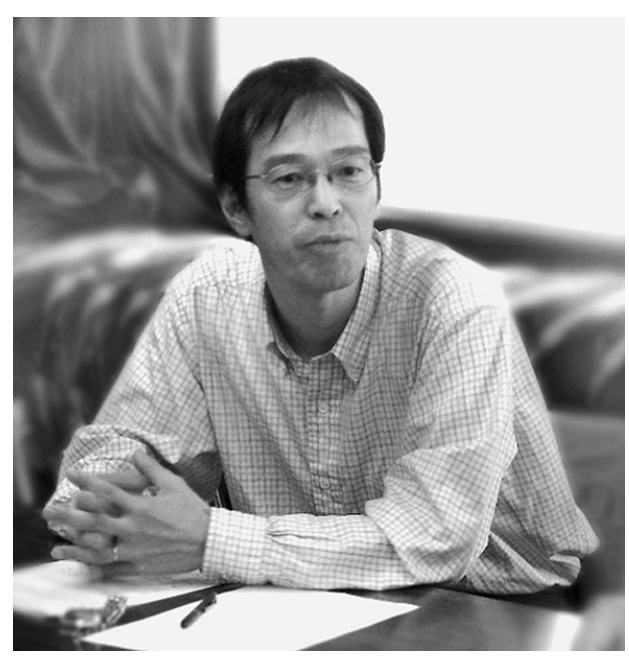

石森浩一郎

神取 それでは最後に，敃待たせしました。ご専門は 生物無機化学, 石森さん报願いします。

石森 出身は工学部石油化学で, そこで量子化学を勉 強して，世の中は生物まで含めて，全部物理法則が支 配するはずだと思ったんですよね。で，4年生になっ て研究室を選ぶときに，金属タンパク質を研究してい る研究室があって, 金属タンパク質だと金属イオンの スピンとか電子っていらのが，直接その機能にかか わっていて，そこでは生物的な現象が物理的に解釈で きるよらな気がして，そこで研究を始めたんです。生 物物理の 100 号記念誌を読久返すと，小谷先生が，金 属タンパク質が生物と物理をつなぐ 1 つの懸け橋に なって，生物のいろんな挙動を物理の言葉で話をした い,そらいら意図でこの学会を作ったって話がありま した。 50 年も前の指摘通りに, いまでは, 金属タン パク質以外もタンパク質の構造や機能を支配する物 理っていらのがある程度わかってきましたよね。で, これから先っていらのは, タンパク質の集合体である タンパク質複合体とか，その上の階層である細胞とか に，その物理の法則をどらいらららにもち込んでいく か，といらことで，最初に話がありましたけども，ど こかに生物と無生物の境があって，それが同じ物理法 則で果たして越えられるのかどらか，それが問題です よね. 伊藤さんいわれたよらにやっぱりわれわれがま た知らない何かが物理法則の中に残っていて，それを 明かさなきゃタンパク質分子と個体の挙動はつなげな い、そんな法則は見つけようとしても見つけられるわ けではないので, タンパク質の分子をきちっと構造決 めて相互作用決めて，それが細胞や組織の中でどんな
ことしてるんだろらって，ミクロ構造からの研究者は 常に上の階層を意識して研究していくうちに何か糸口 がつかめないか，いらことでしょらね。

木寺 今までの报話の中では, ケミストリ一の立場を はじめてはっきりといわれた発言でした。先ほどまで は，物理学と生物学しか話に出ませんでしたが，ヶミ ストリーの立場, ケミストリーの観点, ケミストリー のものの考方方で，生物物理学はこら展開できますと いらょらなことはないでしょらか.

石森 化学というのはものつくりが基本で，ある生命 現象や物理法則があったとすると，それと同じ挙動を するものが作れないかといら発想ですよね。 そういう 意味では化学っていらのは, 生物と物理をつなぐ役割 としては独自のものなんですが，どこからどこへつな ぐのか, あまり認識できていないところがあって，化 学の分野では，化学のセンスはあっても生物や物理の センスが決定的に不足しているところがあるような気 がします。化学はもっと，物理，あるいは生物のべー スの人の意見を聞いた活らがいいところもあるのでは ないかな，と思います。

木寺 1 つのミストリーの定義として,「ケミカル リアクションを扱ら」っていらところがあると思うん です。先ほど生物学の問題として階層の上のほうの議 論をしていきましたけど，その下層の至らのもっと詳 細なケミカルリアクションのメカニズムを理解しま しょらといら研究はどらでしょらか。上の泀らだけ じゃなくて下の泀らもいくらでもフロンティアはある んじゃないかといら気がするんです。

石森 確かにたとえば金属タンパク質のスピン状態を 制御するっていっても，どらいうファクターが制御す るかっていらのがいまだによくわかっていない。ご指 摘の通り，分子よりも下の階層も十分理解できていな いといらことなんです.

神取 それは非常に大事な話ですよね. たとえば resting state の結晶構造はいろいろある.ところが, やっ ぱりケミカルリアクションは，遷移状態を越えていく ところを実験データで捉えないと。この実験データを ぞらやって出すかっていらのは難しいですよね.

安田 私が質問したいのは，化学反応は生命反応と同 義としていってしまっていいかどらか. つまり化学反 応と生命反応っていら反応系で考光たとき，そこに ギャップがあるとしたら, 従来の化学反応は空間軸の 情報がなかった。試験管の中だから。ところが，生 命っていらのは化学反応の中に空間軸と時間軸があ る.それが規則性のある不均質な場を作ることにつな がるのではないですか. 
石森 試験管の中でも，細胞の中でもまわりの条件が 同じであれば，化学反応はまったく同じだと思いま す。ただ，それが「いつ」，「どこで」起こるかが重要 で，たとえば生体の中では何千種類もの化学反応が起 こってますけど，それをある1つの試験管の中で同時 に起こしたところで，それは生命とまったくかかわり のない反応になってしまいますよ水。生体の反応はい つどこでお互いにどらいら相互作用しながら起こる かっていら，時間軸，空間軸があって，そこにわれわ れの知らない部分がある。それが生命と無生物の違い かなとも思らんです。

安田まさに拈っしゃると打りで，たとえば色素細胞 で空間的な色のパターンがある。これは細胞の動きで すね. 一方, 化学振動で起きる空間パターンっていら のは，エレメントが分子なんですよ。だけど同様な空 間パターンができる，といらことは細胞を絶対使わな きゃいけない訳ではなくて，その基本は空間と時間の 両方の次元を含んだ微分方程式な訳ですよね。それを 満たすよらな動さができるものであれば同じ現象が出 てくる.これが物理の言葉じゃあないでしょらか。た としたら細胞を使ってなくても，それはたとえば無機 材料を使ったものであっても，それを生命現象って いっちゃまずいんですかね? 生物物理の世界におい ては. (笑)

神取 最後にソサイエティの話をして括きたいと思い ます。生物物理といらのはもともと，非常に学際的な ものとして始まっている一方，大学などでは生物物理 を名乗っている組織が姫とんどありません。たとえば 石森さんも私も化学といら組織に扣り，人を育てる ことを考えると，生物物理は学問としてどのように 未来を作っていけるのか，などと考えることがある わけですが，このことについて意見をいただきたいと 思います。

若槻 神取さんの質問の意味をまだちょっと掴みさ れてないんですけぞ, ソサイエティのことなのか大学 の研究室, 学科を立ちあげるべきと抽しゃっている のか.

神取 生物物理学会では, 会員数も学会発表も右肩あ がりで伸びてきています。これは50周年のパネル ディスカッションのときに示した通りで，私にとって も驚きだったんですけれぞ，この増加傾向があと 50 年そのまま伸びるとは普通は思わない。そのとき に学科がないことが問題にならなければいいのだけれ ど，といらようなことですね.

安田私たちは,「生物物理学科」といらところにみ
んなが就職してる訳ではなくて，いろいろな組織から 来ている。 これこそまさに生物物理の本質を示してい るのかなと思います。たとえば募集する側から見れ ば，生物物理の新しい血を 1 人くらい試しに入れてみ ようということで，結果として生物物理との融合をい ろんな分野が試してくれて，生物物理といらへテロな 要素が入っていく.

神取 その学際的といらのは，プラスの面もあるし， マイナスの面もあるんだけど，今の発言は，十分に強 みがあってやっていけるだろらといらことですね。

安田まあ，ぞこの分野まで浸食できるかやってみ るっていらような (笑).そんな可能性をもっている のが生物物理なのかなと. 1 人 1 人の研究者が生物物 理をどら解釈して，どう他の分野にアピールして入っ ていくかという個別の問題で，全体としてはすごく柔 軟性がある.

石森 そのと敃りだと思います。大学の化学科などに なると，固定された学問分野になってしまっていて， 化学会といら大きな学会があって。そういら意味で は，確立された学問分野としてはいいのかもしれない ですけど. 100 号，200号の記念号にも書いてあった んですけど，そんな普通の学会にしてほしくないとい らのが生物物理の伝統だと思らんです。

木寺 すこしネガティブなことをいわせてください. 学際性といらのは先汪ど神取さんもいったように弱み でもある訳ですね。基盤をもたない，足場がない，だ からそれぞれの人が一生懸命自覚的に学際に居続けよ らとしている。しかし，生物物理ですら分野として確 立, 固定化され始めていると感じます。いつまで学問 の際に居続けることができるでしょう。学際である, 足場がないといらことを強みとして活かすような活動 を継続していかなければならないと思っています。

原田 私は若手賞にずっとかかわってきた者として思 らことがあります。他の学会でも若手賞はいくらもあ ると思いますけど，生物物理学会では会員数の割に若 手賞に応募してくる人の数が，毎年 50 人以上もいて, ものすごくレベルが高いんですね. やっぱりすごく若 手は元気がいい，将来とても有望だといらことをとて も感じています。若手賞を若い人たちはたいへん憧れ ていて，みんないつかは取りたいといら感じがありま す. それが生物物理学会の未来が明るいことの1つの 根拠になり得ると思っています.

木寺 たしかにそれはすばらしいことですね.

伊藤 確かに会員数は右肩あがり, 年会発表数も右肩 あがり，若手奨励賞はきわめて優秀です。ただ方 で，年会のシンポジウムだとか発表件数見たときに， 
分野が構造生物学と分子モーターに偏りすぎているよ らに思います。 どらしても，へテロといらのが生物物 理学会の最大の売りであるならば, やっぱりそこを もっと補強していかなければならないって思っていま す. 生物物理は生物の人も化学の人も物理の人もとに かく入りやすくすることが最大のポイントだと思って います。

安田 たとえばセッションといら形で，たと壳ば他の 学会で，計測技術のセッションとか, 神経関係のセッ ションをやると，その分野の人が生物物理に流れてく る，そらいらことはあり得ませんか.

伊藤おっしゃる通りです。他の学会に飛び込んで いってシンポジウムをやってしまら。逆に，生物物理 で異なる分野のシンポジウムをやって，そのオーガナ イザーは会員になってください亦ということをやって
いくとか。そんならうに切り口を広げていくのは生物 物理学会にとってきわめて重要だと思います。

望月 安田さんと伊藤さんが拈っしやったことで，私 はどちらかといらと，あそこは行きやすいっていら雲 囲気を作って入ってきてもらら泀らがいいと思うんで す.今年の生物物理の年会でも，発生生物の人たちが ごそっと来て発表しているよらなセッションがありま

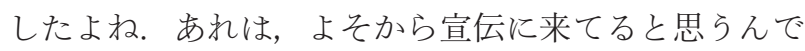
すけども，生物物理の人も発表していて，すごくいい なと思いました。それで，伊藤さんがいわれたことに かかわって，やはり中心となって看板となるよらな分 野はある程度あって，その上でこら裾野が広がってい るのがいいんじゃないかって私は思います。

神取・木寺これぐらいで公式なところは抄わりにさ せてもらって…後はワインを飲みながら‥(ざわざわ)
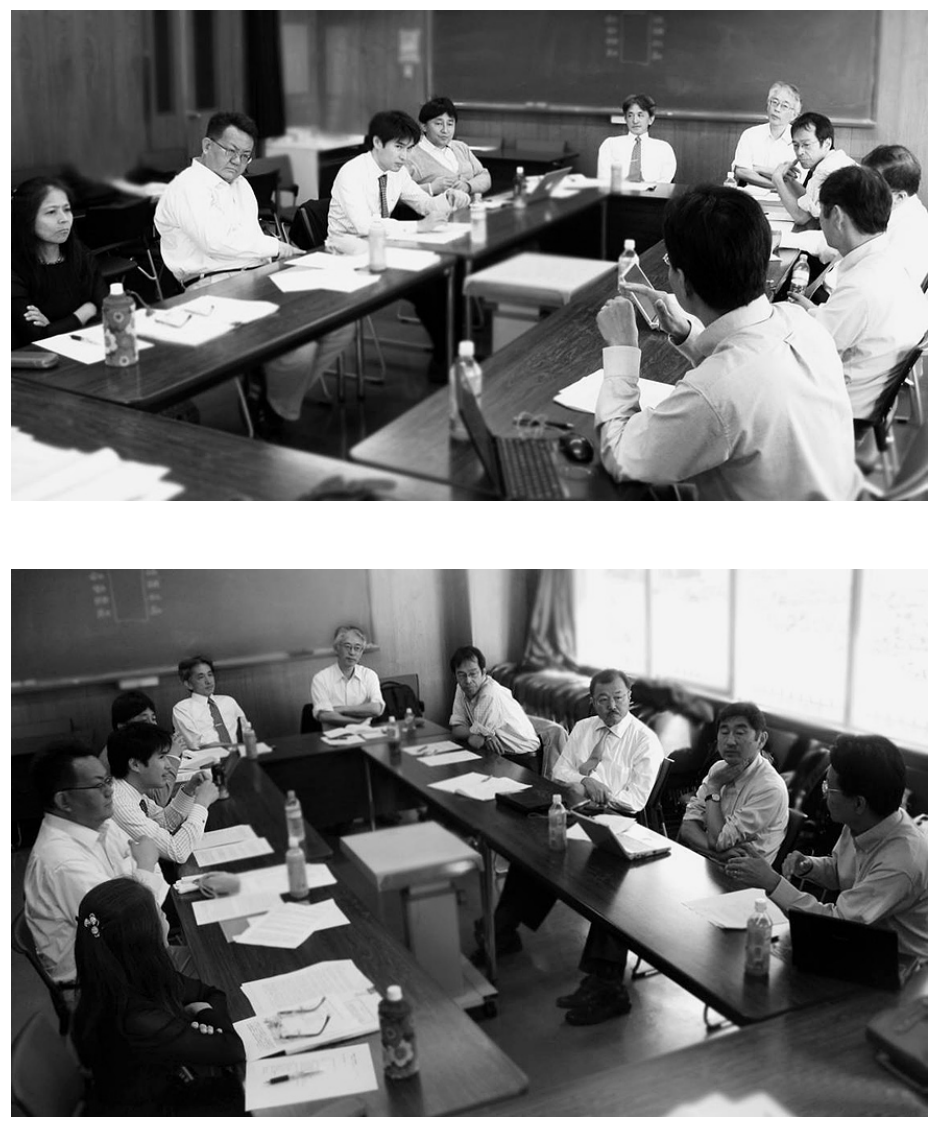

4 時間を超える白熱した議論は，テープを起こして 字数を数えると 8 万字に達しました。 これを 2 万字に まとめるのはたいへんな作業であり，身を削るような 辛さがありました。それでも結果的に，運営委員会に 拈約束したページ数からは 1 ページ超過してしまいま した．本紙面の活字として，その場の雾囲気が十分に 伝えられているかどらかわかりません。読者の皆さま
におかれましては，ここに紹介した座談会記事から出 席者が抱く「生物物理の未来」への熱い思いを少しで も味わっていただけたら幸いです。

最後に献身的なテープ起こし作業を行ってくださっ た会長室の垣内香里さんに心ょり感謝の意を表したい と思います。

(司会: 神取，木寺） 